\title{
THE RELATION BETWEEN RAINFALL, DRAIN DIS- CHARGE AND DEPTH OF THE WATER TABLE IN TILE-DRAINED LAND ${ }^{1}$ )
}

\author{
J. WESSELING \\ Institute for Land and Water Management Research, Wageningen ${ }^{2}$ )
}

\section{SUMMARY}

A description is given of a recording drain gauge and a ground water level recorder. With these devices measurements were taken at three field sites where the soil was light clay.

Ground water levels were recorded midway between tile lines. The shape of the ground water table perpendicular and parallel to tile lines was determined by means of water table measurements in water gauge tubes.

A comparison was made between the actual storage capacity of the soil and the storage according to the moisture sorption curve of the soil. Generally the first is one-half to twothird of the latter value, this being due to entrapped air.

A certain time-lag was observed between the moment that rainfall starts and the drains begin to run. The same also applies to the rise in the water table.

The relationship between the height of the water table and the drain discharge is very variable when the water table is rising, but where it is falling, a good relationship was found. When the water table is shallow the actual discharge is much greater than the theoretical value owing to the greater permeability of the upper layers of the soil.

If drain outfalls are situated below ditch-water level the runoff is considerably retarded.

A method is given for calculating the minimum depth of the water table that may be expected.

\section{INTRODUCTION}

Except in the heavy, recent soils of the new Zuider Zee polders, drain spacings in tile-drained land in the Netherlands are calculated with the aid of steady state formulae developed by Hooghoud (1940). These formulae establish the relationship between discharge, drain spacing, soil permeability, depth of the impermeable layer and the height of the water table midway between tile lines. Calculations of drain spacings are based on the assumption that the discharge is $7 \mathrm{~mm} /$ day when the permissible depth of the water table midway between tile lines is $50 \mathrm{~cm}$ below the surface in arable soils and $40 \mathrm{~cm}$ below the suriace in the case of grassland. Larger discharge coefficients have, however, been proposed (VAN DER Molen, 1953).

Both the permeability and the storage capacity of the soil are important factors in determining the actual depth of the water table in tile-drained land (VISSER (1953), Wesseling (1954)). However, little information is available on the actual storage capacity of soils.

In order to discover whether in a certain drainage system the actual discharge and depth of water table agree with the assumptions made in calculating drain spacings we require simultaneous measurements of drain discharge and depth of water table.

1) $R$ ceived for publication September 17, 1957.

2) Thise investigations were carried out in collaboration with the Laboratory of Physics and M teorology of the Agricultural University. The author wishes to thank Prof. Dr. W. R. vaN WIJK and his staff for their valuable help and advice. 
Despite the fact that a large number of measurements of tile drain discharge are discussed in the literature of the subject (cf. WEssELING, 1954) little is known about the actual relationship between discharge and depth of water table. Most of these investigations were made on sloping fields and do not include measurements of depth of water table and rainfall. Moreover a considerable amount of water finds its way through the relatively high permeable upper layers of the soil as was pointed out by FlonkvisT (1936). Another part of the rainfall on sloping fields never reaches the tile lines while it seeps away through the subsoil to lower parts of the field.

For the above-mentioned reasons the results of these investigations are not applicable to drainage systems in flat soils. Discharge measurements in flat soils are given by KirkhaM and De Zeeuw (1952), VAN DER Molen (1955) and VERHOEven (1953). In these investigations individual measurements were made of discharge and ground water level. Since there are variations in both drain discharge and water level at very brief intervals, continuous measurements are desirable. The author therefore used recording apparatus for drain outfall, water level and rainfall. A description of these devices and some results of measurements made with them will be given below. The measurements were made during the winter of 1955-1956.

\section{Apparatus ${ }^{3}$ )}

The rainfall was recorded with a commercial type of recording rain gauge commonly used in the Netherlands by the Royal Meteorological Institute (KNMI).

Drain discharges were recorded by means of an apparatus similar to the one described by ChiLDs (1939). The meter consists of a rectangular brass tank $30 \times 20 \times 20 \mathrm{~cm}$, one end of which is closed by an interchangeable diaphragm of stainless steel $1 \mathrm{~mm}$ thick in which were drilled a number of rows of circular holes. The diameter of the holes was $4 \mathrm{~mm}$ and the distance hetween the rows $1 \mathrm{~cm}$. The number of holes in each row can be calculated from the flow through one opening so as to obtain a linear relationship between outflow and height of water in the tank. The level of the water in the tank is recorded by the line drawn on a clock-driven drum as a pen is moved vertically by means of a float. The float works in a vertical tube to which the water has access through holes made in the base. In this way it is possible to estimate easily the total quantity of water passing through in any given interval of time.

A transverse brass screen with openings of $2 \mathrm{~mm}$ diameter removes the coarser particles entrained by the water and prevents them from blocking the holes of the diaphragm. The clock mechanism and pen are protected by a polyethylene cover which is readily removable.

The ground water level recorder is based on the principle described by Thijssen et al. (1954). The apparatus (Fig. 2) consists of a mercury manometer connected to a rubber bag by means of a rubber tube. The rubber bag is protected by a brass screen and placed at the bottom of the water gauge tube. Rubber bag and tube and the right-hand leg of the manometer are filled with

3) With the exception of the recording rain gauge, the apparatus were constructed by the Laboratory of Physics and Meteorology. 


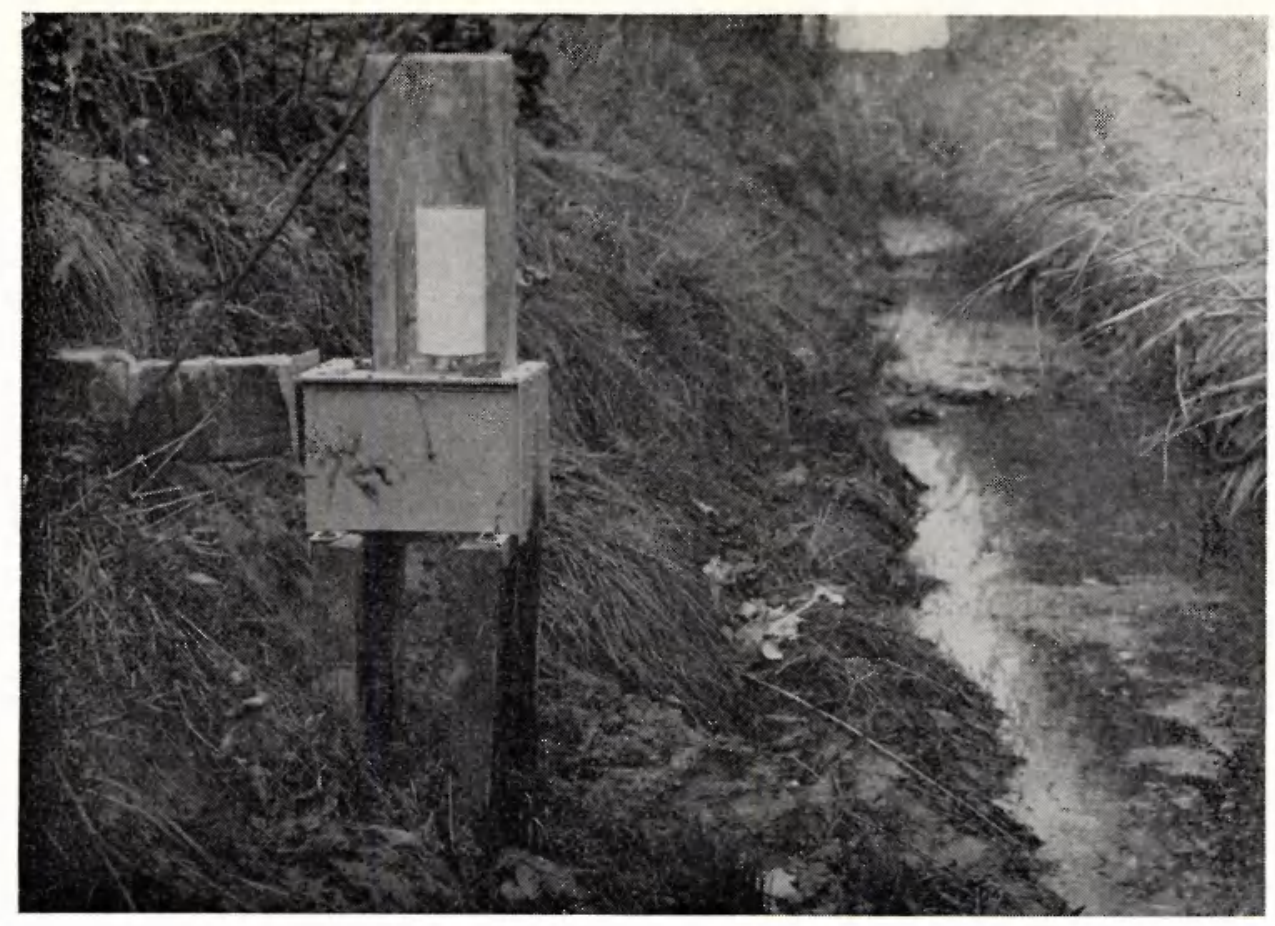

Fig. I Setup of tile drain discharge meter in the field.

a nonfreezing liquid (ethyl alcohol $50 \%$ ). In the left-hand leg of the manometer is mounted an iron float connected to a writing pen.

The relationship between the displacement of the mercury in the left-hand leg of the manometer and the water table in the water gauge tube depends on the diameters of the manometer legs. These diameters are such, that a $1 \mathrm{~cm}$ displacement of the float represents a difference of $15 \mathrm{~cm}$ in the ground water level.

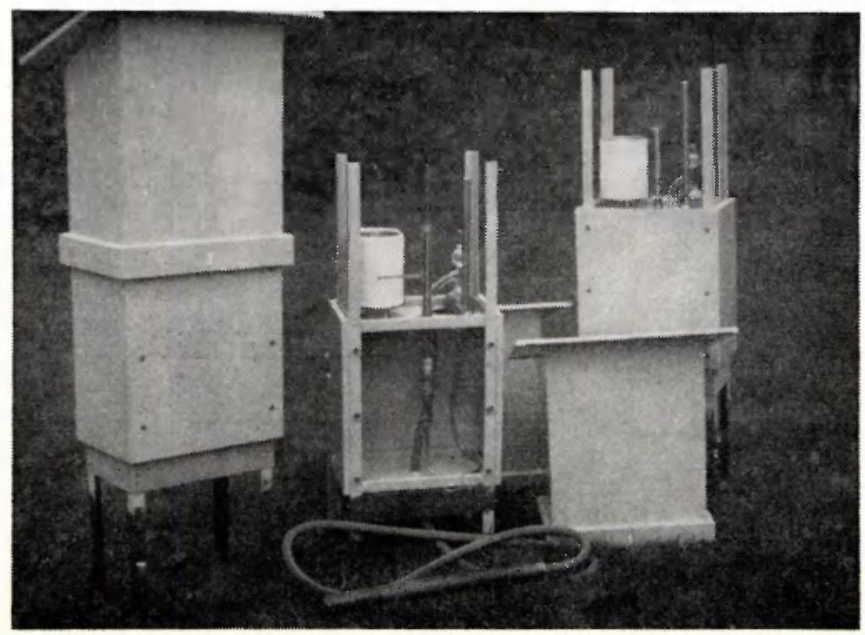

Fig. 2 Groundwater Level. Recorders. 


\section{EXPERIMENTAL FIEIDS}

The measurements were taken at three field sites where the soil was homogeneous light clay. The clay content in the upper layers was about $30 \%$ and decreased to about $5-10 \%$ at a depth of $150 \mathrm{~cm}$.

On site I the tile lines had a length of 196.5 metres and a distance apart of 17 metres. The depth of the tile lines ranged from $90 \mathrm{~cm}$ below the surface at the upper end to $120 \mathrm{~cm}$ at the outfall. The level of the water in the outfall ditch was maintained at a constant level of $80 \mathrm{~cm}$ below the tile outlets by means of an electric pumping plant.

On sites II and III the tile lines had a length of $114.5 \mathrm{~m}$ and the drain spacing was $30 \mathrm{~m}$. The depth of the tile lines on these sites was the same as on site I. In this case the ditch water level was maintained at $45 \mathrm{~cm}$ below the drain outlets by means of a pumping plant driven by wind-power. In periods of heavy rainfall and too little wind the ditch water rose to a level above the drain outlets. During these periods no drain discharges could be recorded.

The arrangement of the metres and water gauge tubes in the trial fields is shown in Fig. 3. All water gauge tubes reached to a depth of $150 \mathrm{~cm}$ and

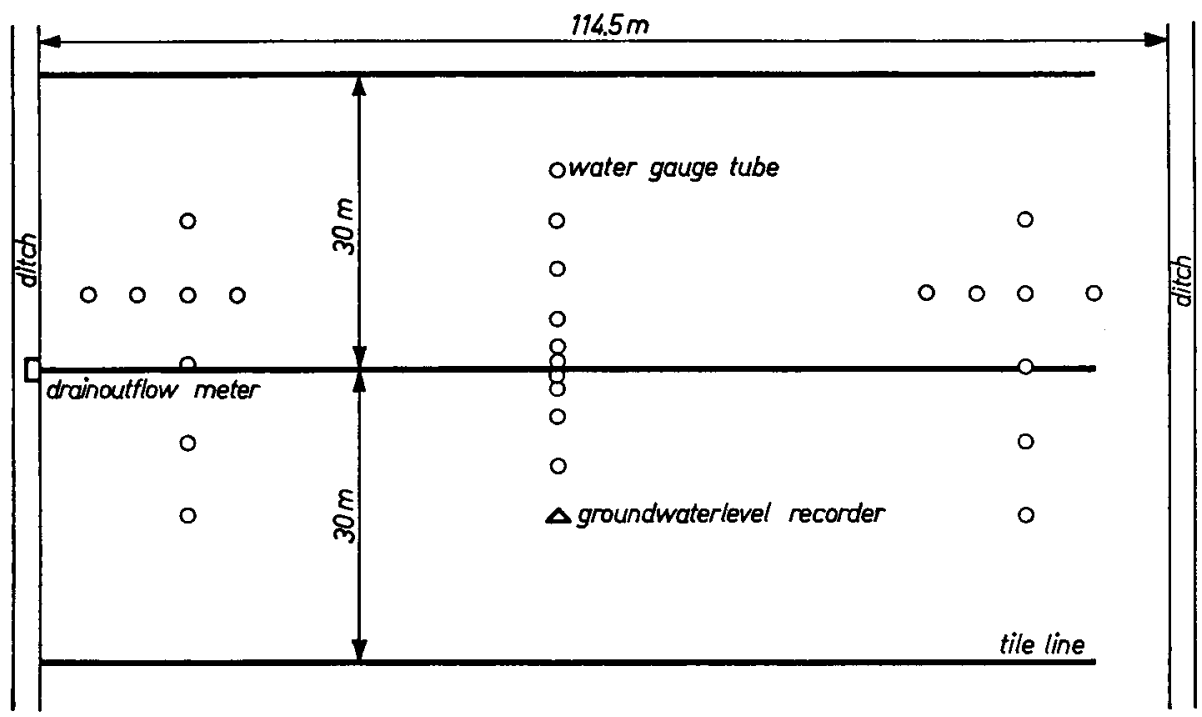

Fig. 3 Appointment of drain discharge meter, groundWater Level hecorder and Water GAUGE TUBES DURING DRAIN FLOW MEASUREMENTS.

consisted of concrete drain tiles having an inside diameter of $5 \mathrm{~cm}$. The depth of the water table in the tubes was measured once a week at the same time as the recording strips of the clock mechanisms were renewed. The first measurement was taken on September 15th 1955 and the last on April 15th 1956.

The permeability of the soil was determined by means of the auger hole method (VISSER, 1954). The results of these measurements are listed in table 1. 
Table 1 Permeability of the soil, determined by auger hole method.

\begin{tabular}{c|c|c|c|c}
\hline Site & Depth (m) & $\begin{array}{c}\mathrm{K} \\
\text { (metres per day) }\end{array}$ & Depth (m) & $\begin{array}{c}\mathrm{K} \\
\text { (metres per day) }\end{array}$ \\
\hline \multirow{3}{*}{ I } & $0.95-1.45$ & 0.53 & $0.95-1.90$ & 0.23 \\
& $0.95-1.40$ & 0.58 & $0.95-1.90$ & 0.29 \\
& $0.95-1.35$ & 0.47 & $0.95-1.85$ & 0.43 \\
II & $1.00-1.40$ & 0.14 & $1.00-1.90$ & 0.35 \\
& $1.00-1.35$ & 0.13 & $1.00-1.95$ & 0.27 \\
& $1.00-1.40$ & 0.11 & $1.00-1.95$ & 0.27 \\
III & $0.95-1.35$ & 0.25 & $0.95-1.90$ & 0.26 \\
& $0.95-1.30$ & 0.24 & $0.95-1.90$ & 0.30 \\
& $0.95-1.40$ & 0.26 & $0.95-1.90$ & 0.25 \\
\hline
\end{tabular}

The theoretical drain spacing was calculated by Hooghoudr's (1940) formula

$$
I^{2}=\frac{8 K_{o} d m_{o}+4 K_{b} m_{o}^{2}}{s}
$$

in which

$l=$ drain spacing in metres,

$K_{o}=$ permeability of the soil below the tile lines in metres per day,

$K_{b}=$ permeability of the soil above the tile lines in metres per day,

$m_{o}=$ height of water table midway between and above tile lines in metres,

$s=$ drain discharge in metres per day,

$d=$ thickness of equivalent layer (tabulated by HooghoudT).

Assuming the mean drainage depth to be 1 metre, $m=0.5 \mathrm{~m}$ and $s=$ 0.007 metres/day, table 2 gives the theoretical and actual drain spacing.

Table 2 Actual and theoretical drain spacings in the experimental fields.

\begin{tabular}{r|c|c}
\hline Site & Actual & $\begin{array}{c}\text { Drain spacing in } \\
\text { metres theoretical }\end{array}$ \\
\hline II & 17 & 16 \\
III & 30 & 13.5 \\
& 30 & 14.5 \\
\hline
\end{tabular}

\section{DEPTH OF WATER TABLE}

On September 26, 1955 the depth of the water table on the three sites was $1.45,1.75$ and 1.95 below the surface. After excessive rainfall during the last days of September the water level rose above the level of the tile lines and drain discharge started.

The ground water levels during the measuring period are listed in table 3 .

Table 3 Depths of water table midway between tile lines during the period October $10-$ February 15.

\begin{tabular}{r|c|c|c|c|c|c}
\hline Site & $0-30$ & $30-50$ & $50-70$ & $70-90$ & $>90 \mathrm{~cm}$ & $\begin{array}{c}\text { Below } \\
\text { surface }\end{array}$ \\
\hline I & 0 & 4 & 13 & 49 & 64 & days \\
II & 10 & 33 & 29 & 19 & 39 & days \\
III & 5 & 29 & 39 & 37 & 20 & days \\
\hline
\end{tabular}


It is evident that on sites II and III, in which the drains were spaced widely apart, shallow water tables occur during several days. On site I the water table generally remains at a greater depth than $50 \mathrm{~cm}$ below the surface.

From the observed data of the level in the water gauge tubes it was possible to determine the shape of the water table in the middle of the site and at right-angles to the tile lines. Fig. 4 shows this shape for four data each on sites II and III.

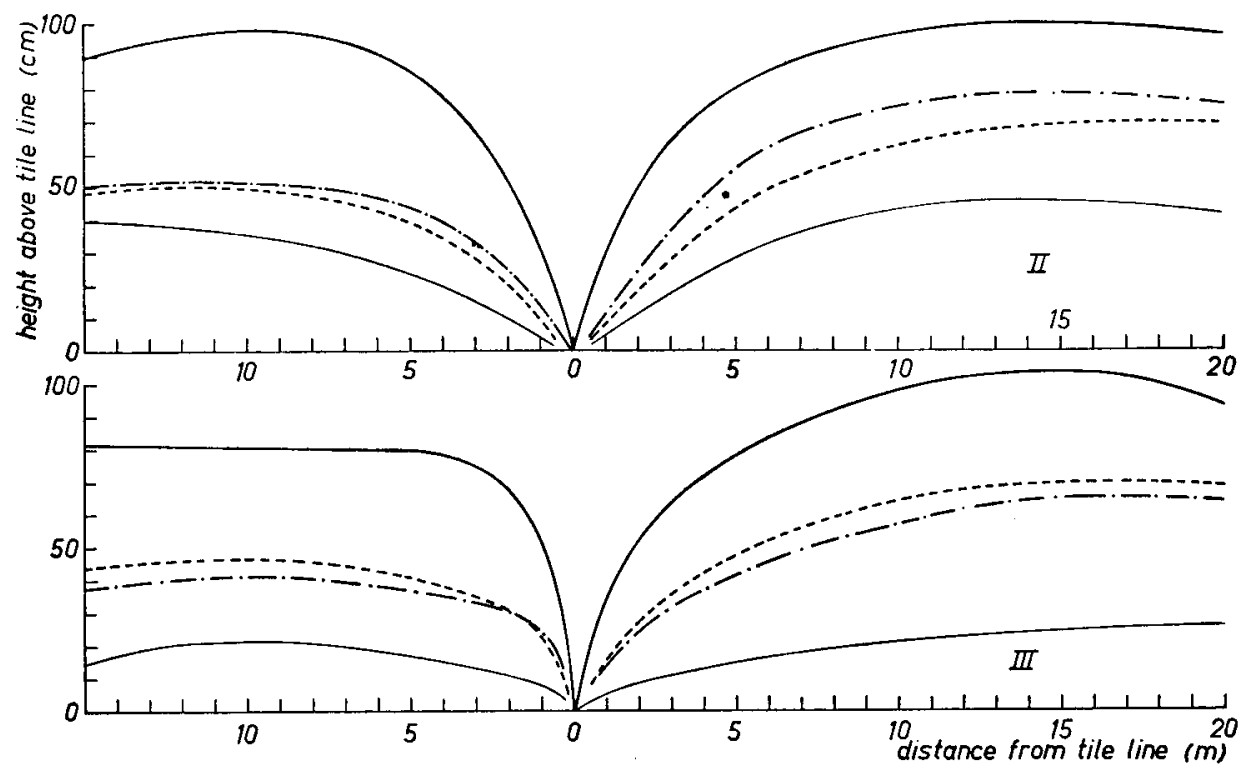

Fig. 4 Shape of the groundwater table IN Parcel II and III perpendicular to tile LINES ON JAN. 30 (- $(-)$, JAN. 2 ( Distance BetWeEN TILE LINES IS $30 \mathrm{M}$.

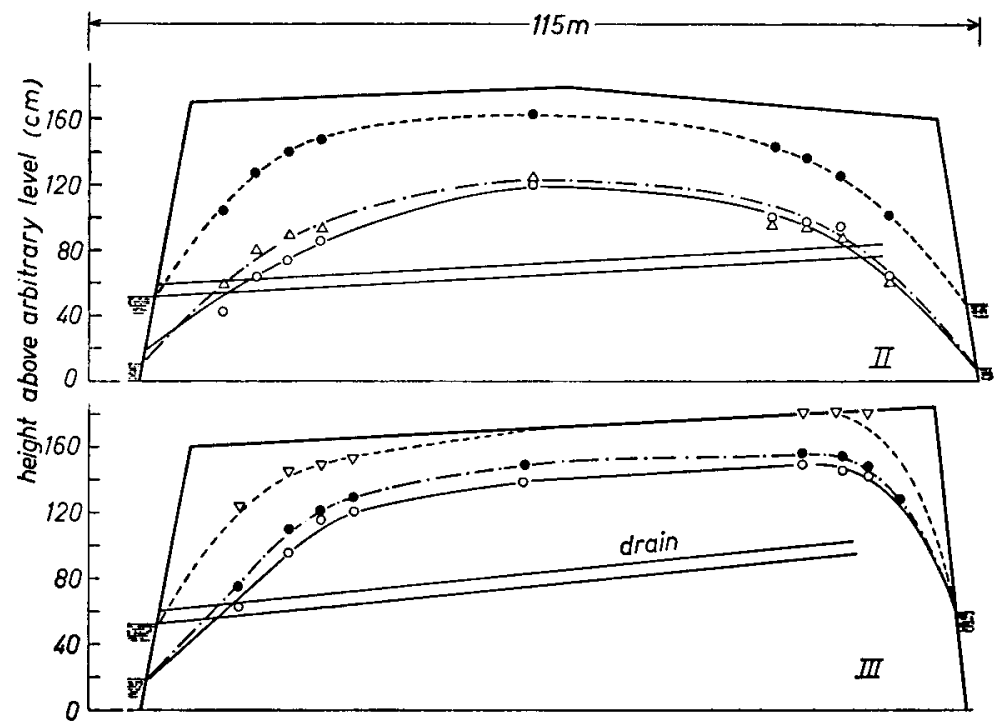

Fig. 5 Shape of the groundwater table in parcel II and III parallel to tile lines

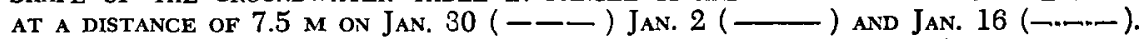
Drain spacing is $30 \mathrm{M}$. The distance Between the Ditches is $114.5 \mathrm{M}$. 
The lower level of the water table on the left-hand side of the tile lines is due to an old drainage system which conveyed water to the new system.

Fig. 5 shows the shape of the water table parallel to tile lines on sites II and III. It is clear from this figure that part of the rainfall drains directly to the ditches. The magnitude of this drainage depends on the height of the water table and the ditch level and is still unknown.

\section{StORAGE CAPACITY OF THE SOIL}

By storage capacity is meant that volume per unit depth of soil which is able to take up water. It can, in fact, be calculated from the moisture sorption curve, assuming there is equilibrium between the phreatic level and the moisture content of the soil above this level. The method of calculation is shown diagramatically in Fig. 6.

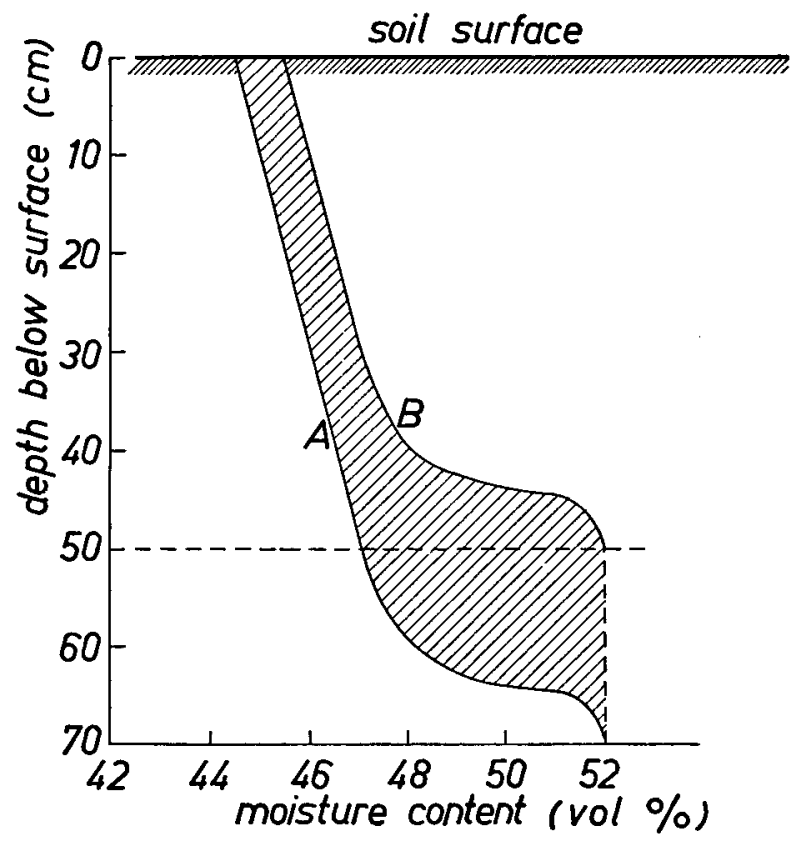

Fig. 6 Calculation scheme for storage capacity of the soll.

In case $A$ the phreatic level is at a depth of $70 \mathrm{~cm}$ below the surface and the moisture content of the soil is shown by the left-hand curve (moisture sorption curve of the soil). In case B the ground water level is $50 \mathrm{~cm}$ below the surface. In this case the moisture content of the soil is shown by the righthand curve. The storage capacity of the soil is then the difference in moisture content, expressed in $\mathrm{cm}$, divided by the difference in ground water level (in this case $20 \mathrm{~cm}$ ).

The actual storage capacity differs from the theoretical value. In the first place there may be a certain moisture deficiency or excess. In practice these factors will have little effect during periods when evapotranspiration is slight and sufficient time has elapsed after the rainfall. Secondly, a certain amount of air may be entrapped in the soil. This factor is of far more importance, 
and as result of this phenomena the actual storage capacity will usually be much smaller than the theoretical value.

Actual storage capacity was calculated from rainfall data and rise in the water table. This was only done for short periods (of up to four hours) when the discharge can be ignored. Some of the results are listed in table 4.

Table 4 Actual and theoretical storage capacity of the soil.

\begin{tabular}{|c|c|c|c|c|c|}
\hline \multirow{2}{*}{ Site } & \multirow{2}{*}{$\begin{array}{c}\text { Rainfall } \\
\mathrm{mm}\end{array}$} & \multicolumn{2}{|c|}{ Depth of water table $(\mathrm{cm})$} & \multicolumn{2}{|c|}{ Storage capacity } \\
\hline & & from & to & actual & theoretical \\
\hline I & $\begin{array}{r}20.0 \\
4.0 \\
5.1 \\
4.0 \\
5.8\end{array}$ & $\begin{array}{r}100 \\
89 \\
89 \\
95 \\
87\end{array}$ & $\begin{array}{l}58 \\
83 \\
76 \\
87 \\
67\end{array}$ & $\begin{array}{l}0.05 \\
0.07 \\
0.04 \\
0.05 \\
0.03\end{array}$ & $\begin{array}{l}0.06 \\
0.08 \\
0.08 \\
0.08 \\
0.07\end{array}$ \\
\hline II & $\begin{array}{r}17.0 \\
12.0 \\
3.2 \\
5.0 \\
12.0\end{array}$ & $\begin{array}{r}177 \\
125 \\
98 \\
100 \\
88\end{array}$ & $\begin{array}{r}136 \\
82 \\
93 \\
88 \\
58\end{array}$ & $\begin{array}{l}0.04 \\
0.03 \\
0.06 \\
0.04 \\
0.04\end{array}$ & $\begin{array}{l}0.07 \\
0.09 \\
0.09 \\
0.07 \\
0.07\end{array}$ \\
\hline III & $\begin{array}{l}4.2 \\
6.0 \\
6.0\end{array}$ & $\begin{array}{l}86 \\
74 \\
50\end{array}$ & $\begin{array}{l}81 \\
59 \\
37\end{array}$ & $\begin{array}{l}0.08 \\
0.04 \\
0.05\end{array}$ & $\begin{array}{l}0.08 \\
0.07 \\
0.06\end{array}$ \\
\hline
\end{tabular}

The actual storage is about one-half to two-third of the theoretical value. The mean actual storage in the three sites was $0.05,0.04$ and 0.05 .

Actually storage capacity can also be calculated from drain discharge and fall in the water table, but since it is not known how much water drains directly to the ditch considerable errors may be anticipated with this method.

\section{Drain DISCHARGE}

Drain discharges were recorded at one drain outflow at each site. At sites II and III no large and moderate large discharges could be recorded owing to the high ditch-water level during periods of heavy rainfall. The results of the recordings at site $I$ are tabulated in table 5 together with the rainfall.

Table 5 Drain discharge and rainfall in the period Oct. 1-April 1 (exclusive February) at site I.

\begin{tabular}{|c|c|c|c|c|c|}
\hline & $0-3$ & $3-5$ & $5-7$ & $7-10$ & $>10 \mathrm{~mm} / \mathrm{day}$ \\
\hline $\begin{array}{l}\text { Discharge } \ldots \ldots \\
\text { Rainfall } \ldots \ldots\end{array}$ & $\begin{array}{l}123 \\
122\end{array}$ & $\begin{array}{r}15 \\
8\end{array}$ & $\begin{array}{r}4 \\
11\end{array}$ & $\begin{array}{l}2 \\
1\end{array}$ & $\begin{array}{l}10 \text { days } \\
12 \text { days }\end{array}$ \\
\hline
\end{tabular}

In order to convert the total amount of discharge to $\mathrm{mm} /$ day it is assumed that of the total length of 196.2 metres a length of 26.2 metres drained directly to the ditches. This assumption was based on the water balance of the site during the periods Oct. 17-23 and Dec. 19-Jan. 31. The storage of water in the soil was calculated from the storage capacity and the differences in the shape of the water table at the beginning and at and of the balance period; 
evapotranspiration was calculated with the formula of Penman (1948). The results of these calculations are presented in table 6 .

Table 6 Water balance for site I during the periods Oct. 17-23 and Dec. 19-Jan. 31. Data are given in $\mathrm{mm}$.

\begin{tabular}{|c|c|c|}
\hline \multirow{2}{*}{ Balance factor } & \multicolumn{2}{|c|}{ Period } \\
\hline & Oct. $17-23$ & Dec. 19-Jan. 31 \\
\hline Rainfall & +40.0 & +124.1 \\
\hline Discharge & -29.6 & -113.5 \\
\hline Storage & -7.3 & -10.0 \\
\hline Evapotranspiration $\ldots \ldots \ldots$. & -3.6 & -14.0 \\
\hline Difference $\ldots \ldots \ldots \ldots \ldots$ & $-1 \%$ & $-13.5 \%$ \\
\hline
\end{tabular}

This table shows that the above assumption leads to a fairly good agreement. Part of the difference is due to the difference in discharge from the neighbouring tile lines. In the first period relatively large discharges were recorded. The discharge was somewhat reduced by the meter of which the capacity was too small. In periods of small discharges, however, the discharge from the neighbouring tile lines is less than that from the recorded tile line. A comparison of the discharges of the neighbouring drain tiles is given in Fig. 7 .

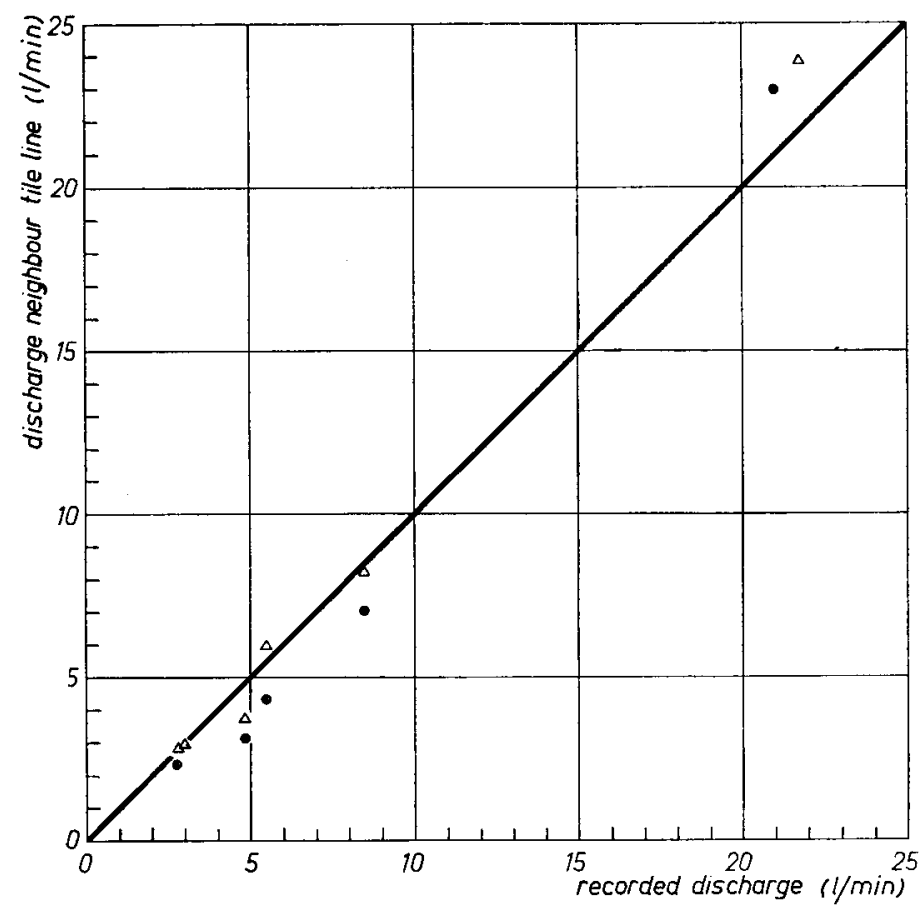

Fig. 7 RELATION BETWEEN THE RECORDED DRAIN OUTFLOW AND THE OUTFLOW FROM THE TILE LINE AT THE LEFT ( $\bullet$ ) AND RIGHT HAND SIDE $(\triangle)$. 
ThE RELATIONSHIP BETWEEN DRAINS DISCHARGE AND GROUND WATER LEVEL

Fig. 8 shows the trend of the drain discharge, the ground water level midway between tile lines and the precipitation for the period Jan. 23-29.

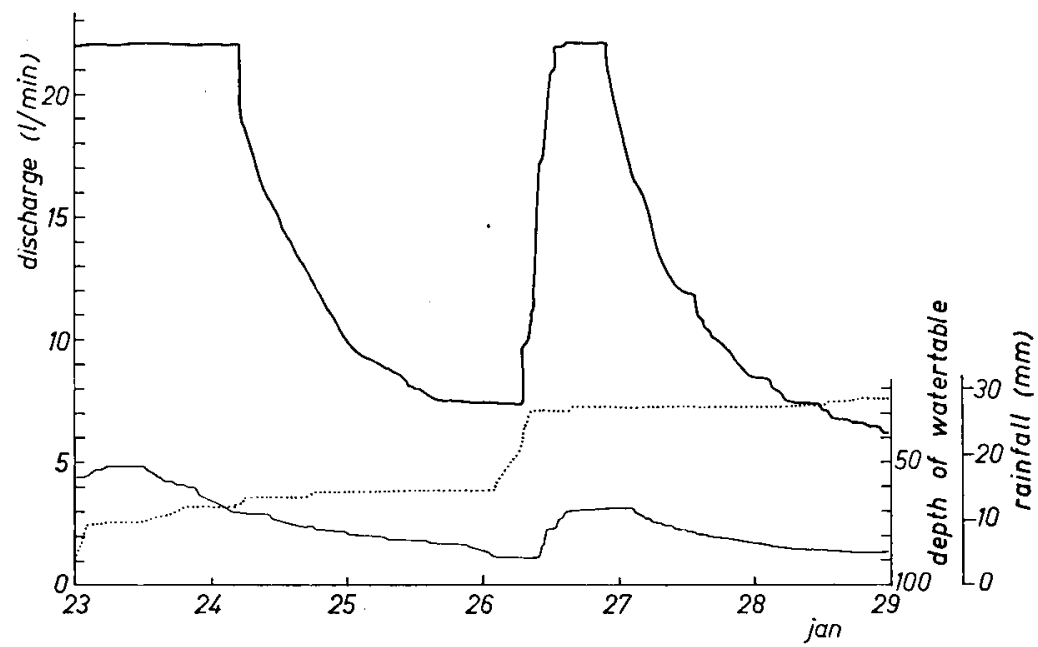

Fig. 8 Course of Drain discharge ( - ), Groundwater LeVel midWay between tile lines ( - ) AND PREcipitation ( ---- ) ON PARCEL I DURING THE PERIOD JANUARY 23-29.

In this figure the insufficient capacity of the meter is shown by the flattened peaks of the drain discharge curve.

There is a certain lapse of time between the start of the three phenomena. This is mainly due to the quicker drainage of rain falling near the tile lines. From these and similar curves it is possible to derivate the relationship between drain outflow and depth of water table. For this purpose a distinction has been made for periods of rising and falling water tables. The left-hand side of Fig. 9 shows the result for periods with rising water table. During such periods the relationship between discharge and depth of water is very indeterminate but in the case of a falling water table, a good relationship was obtained.

In Fig. 9 the thick line on the right-hand side indicates the relationship according to eq. $1 . K_{b}$ is assumed to be the same as the measured $K_{o}$. Probably $K_{b}$ is larger than $K_{o}$, owing to root growth in the upper layers. The influence cannot, however, be so large as to explain the difference between the curves. The only conclusion to be drawn from this is that part of water drains through the upper tilled layer.

Although only few large discharges could be recorded at sites II and III the same phenomena was observed. Actual discharges are usually greater than the theoretical ones.

INFLUENCE OF HIGH DITCH LEVELS UPON DRAIN DISCHARGE

At sites II and III no large discharges could be recorded owing to the high water level in the outfall ditch. The reduced hydraulic head resulting from these high levels will reduce the drain outflow. 

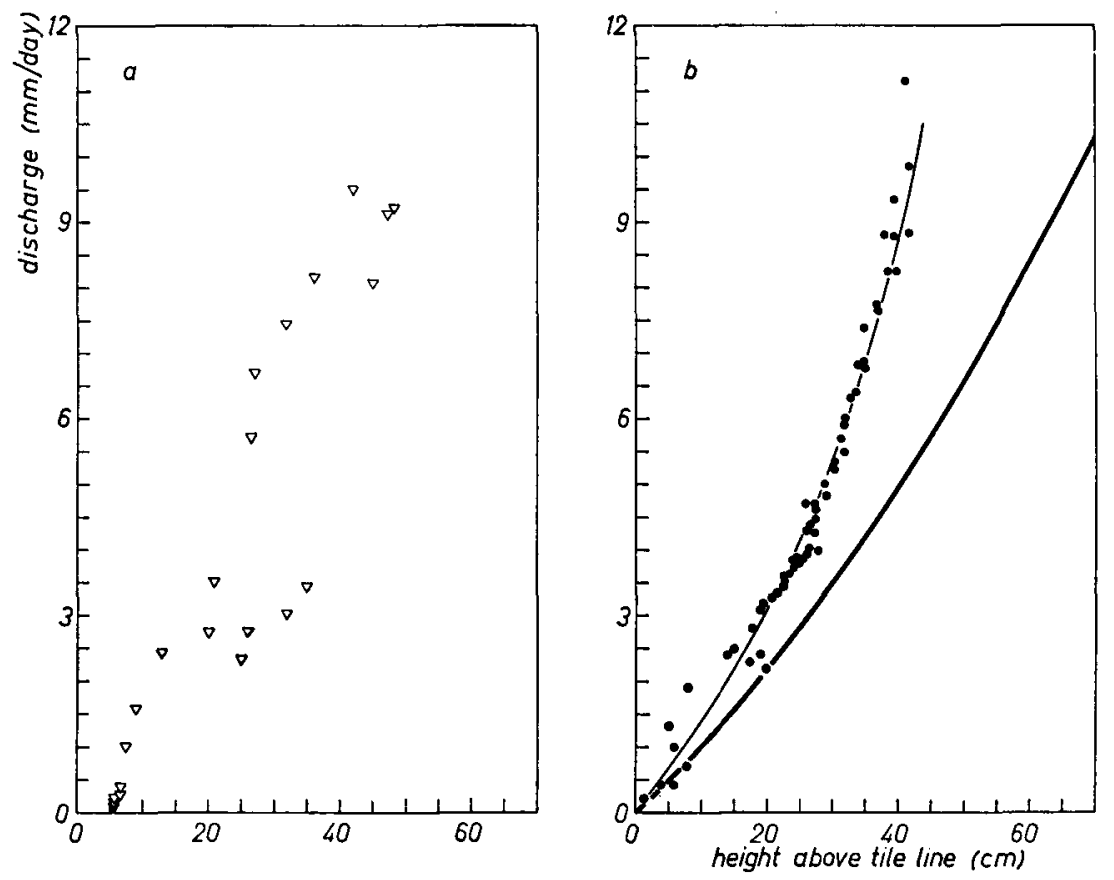

Fig. 9 Relation betweEn dRAin Discharge and heigth of Water table MidWay betweEN TILE LINES FOR RISING (LEFT HAND FIGURE) AND FALLING WATER TABLE (Right haND figure). The thick line Indicates the relation according to EQ. 1.

We will now attent to calculate this influence. As a first approximation it may be assumed that there is a linear relationship between discharge and height of water table. In periods with a falling water table and no rainfall at all the depth of the water table then may be represented by the equation

$$
h_{t}=h_{o} e^{-B t}
$$

in which

$h_{t}=$ height of water table at time $t$,

$h_{o}=, \quad, \quad, \quad, \quad, \quad t=o$,

$B=$ a constant depending on permeability and drain spacing,

$t=$ time in days.

In Fig. 10 the depth of the water table on site II was plotted against the time. During the first five days the ditch water level was above the drain outlets. After the fifth day the ditch water level was lowered about $40-50 \mathrm{~cm}$.

The vertical axis in Fig. 10 has a logarithmic scale. The constant $B$ can therefore be read from the gradient of the line. In the case of the line in Fig. 10, $B=0.06$. If the height of the water table midway between tile lines is indicated by $m_{o}$ and the storage capacity of the soil by $L$, the relationship between the discharge $S$ and $m_{0}$ is shown by

$$
S=B \times L \times m_{0}
$$

or in our case

$$
s=0.06 \times 0.04 m_{o}=0.0024 m_{0}
$$




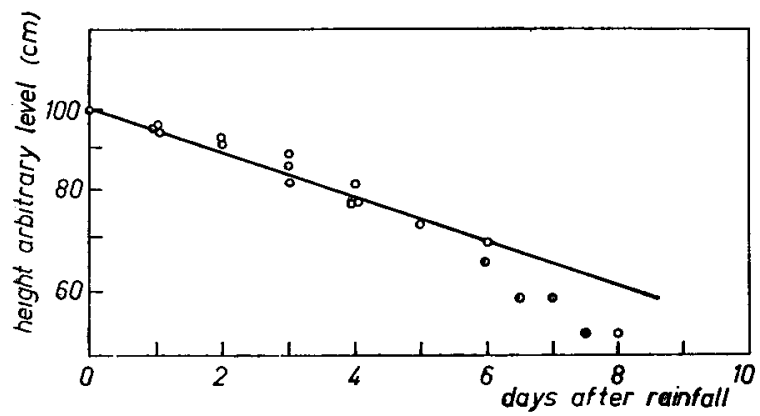

Fig. 10 Fali of the groundwater table on parcel II. During the first five days the DRAIN OUTLETS WERE BELOW THE LEVEL OF THE WATER IN THE DITCH.

Again as a first approximation, the relationship between discharge, drain spacing and other soil properties may be represented by eq. 1, in which the last term of the numerator can be ignored, so that

$$
s=\frac{8 K d m_{0}}{l^{2}}
$$

Substituting the values of $K, d$ and 1 for this site $K=0.25$ metres per day, $1=30$ metres and $d=2.15$ metres gives

$$
s=0.005 m_{0}
$$

Actually the real discharge will be greater than that shown by eq. 6 , assuming the drain outlets to be above the level of the drain outfalls. Hence the retardation in outflow is at least $50 \%$ when the tile outlets are below the water level in the ditch.

WHAT DEPTH OF WATER TABLE IS TO BE EXPECTED?

When the relationship between discharge and height of water table is known for a given drainage system, it is possible to calculate the actual depth of water table caused by a certain rainfall. For site $I$ the relation

$$
s=0.02 m_{0}
$$

is taken from Fig. 9.

According to VISSER (1953) we take, as a first approximation, a constant discharge of $2 \mathrm{~mm} /$ per day. Each rainfall pattern to be expected will then be represented by

$$
r_{i}=a t^{-b} r_{g}
$$

in which

$r_{t}=$ the rainfall on day $t$ in metres,

$t=$ time in days,

$r_{g}=$ the mean precipitation of $2 \mathrm{~mm}$ per day,

$a$ and $b$ are constants. 
According to VISSER the change of discharge caused by the rainfall may be shown by

$$
\frac{d s}{d t}=\left(a t^{-b}+r_{g}-s_{g}-0.02 h\right)
$$

in which

$h=$ the rise of the water table caused by the rainfall.

$s_{g}=$ the mean discharge of $0.002 \mathrm{~m}$ per day,

When $r_{g}=s_{g}$ we obtain from eq. 9

$$
d s=\left(a t^{-b}-0.02 h\right) d t
$$

For a storage capacity $L$ of the soil $d s=L d h$ and

$$
d h=\frac{1}{L}\left(a t^{-b}-0.02 h\right) d t
$$

If we assume that $A=a / L$ and $B=0.02 / L$, it follows from eq. 11

$$
d h=\left(A t^{-b}-B h\right) d t
$$

and also

$$
h=A e^{-B t} \int_{t=0}^{t=t} e^{B t} t^{-B} d t+m_{g} e^{-B t}
$$

in which $m_{g}$ is the height of water table caused by the constant discharge of $2 \mathrm{~mm}$ per day.

From VISSER's table 2 we can compute the value of $a$ and $b$. For a rainfall to be expected once in 10 years $a$ and $b$ are 0.019 and 1.75 respectively.

If a chance of once in 100 years is taken, $a$ and $b$ are respectively 0.025 and 1.50 .

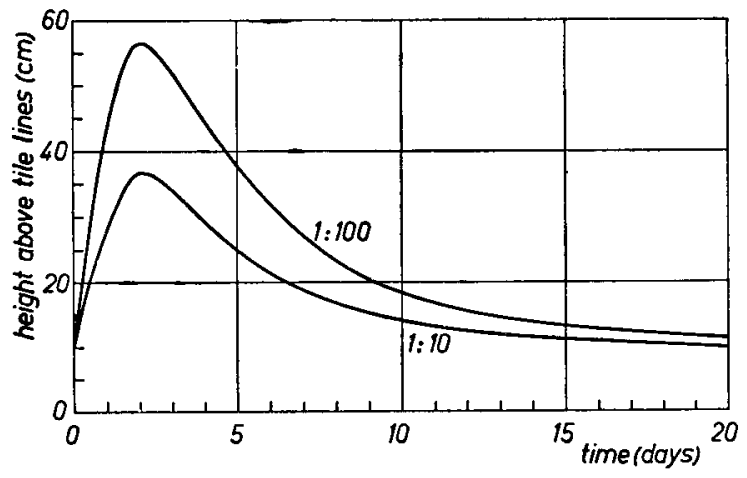

Fic. 11 Height OF GroundWater TABLE MDWAY BetWeEn TILE LINES WhICH CAN BE EXPECTED ONCE IN 10 years aNd ONCE IN 100 years in Parcel I Calculated ACCORDING TO EQ. 13 .

Substituting the above-mentioned values of $a$ and $b$ and the storage capacitty $L=0.05$ for site $I$ in eq. 13, together with $m_{g}$ calculated from eq. 1, we obtain the results given in Fig. 11. This figure shows that no shallow water tables need be expected on this site, or in other words the drainage system on this site is satisfactory. 


\section{BIBLIOGRAPHY}

CHrubs, E. C. : A recording water flow meter. J. of Sci. Instruments 17 (1939) 93-94.

Flodkvist, H. : Kulturtechnische Grundwasserforschung. Sveriges Geologisen Undersöknung Serie C, nr. 371, 1936.

Hooghoudt, S. B.: Bijdragen tot de kennis van enige natuurkundige grootheden van de grond nr. 7. Versl. Landb. Ond. 46 (1940) 515-707.

Kirkham, D. and J. W. DE ZeEuW : Field measurements for tests of soil drainage theory. Soil Sci. Soc. of Amer. Proc. 16 (1952) 286-293.

Molen, W. H. vaN DER : Afvoermetingen in de Noord-Oostpolder, Kampen 1955 (in typescript).

- - : Bepaling van de drainafstanden door een morfologische beoordeling van het bodemprofiel. Landbouwk. Tijdschr. 65 (1953) 105-113.

Penman, H. L. : Natural evaporation from open water, bare soil and grass. Proc. Roy. Soc. of London, A 193 (1948) 120-145.

Trryssen, H. A. C. et al. : New Instruments for Agricultural Research. Neth. J. of Agr. Sci. 2 (1954) 209-214.

Verhoeven, B.: Over de zout- en vochthuishouding van geïnundeerde gronden. Versl. Landb. Ond. 59.5 (1953).

Visser, W. C.: De grondslagen van de drainageberekening. Landbouwk. Tijdschrift 65 (1953) 66-81.

- - : Tile drainage in the Netherlands. Neth. J. of Agr. Sci. 2 (1954) 69-87.

Wesseling, J. : Tile drainage research. Neth. J. of Agr. Sci. 2 (1954) 254-259. 